\title{
DOI: 10.7596/taksad.v9i1.2435
}

Citation: Rakochi, V. (2020). Genesis of the Concerto for Orchestra. Journal of History Culture and Art Research, 9(1), 273-285. doi:http://dx.doi.org/10.7596/taksad.v9i1.2435

\section{Genesis of the Concerto for Orchestra}

Vadim Rakochi ${ }^{1}$

\begin{abstract}
The main goal of this article is to classify the origins of the concerto for orchestra and thus to determine its genesis. The methodologies applied include the analytical (study of literature), the functional (concerto for orchestra in the context of musical culture), and the historical (transformation of the genre due to the evolution of orchestral thinking) approaches. A mainstream tendency for synthesis of different styles within the disappearance of the very concept of 'normalun-normal' regarding the orchestra should be mentioned as the first factor which caused the birth of the concerto for orchestra. No matter how important the changes in the orchestra's functions and structure along with the fusion of different origins for the genesis of the concerto for orchestra were, it is true that it was not a single factor which influenced the genre transformations of the concerto. Search for new sounds and techniques to embody them, popularity of the chamber orchestra, strengthening and diversifying of the 'inside-the-orchestra solo', growth of theatricality in symphonic music, transformation of longstanding genres and amplification of the colorfulness in the orchestra are the principle reasons for the appearance of the concerto for orchestra in 1925. The review of Hindemith's, Petrassi's, Bartók, Tippett's and Lutosławski's concertos demonstrates two different approaches to the synthesis. The conclusion of this article is that the rethinking of the 'old' genres within a tendency to synthesize different styles and to merge dissimilar music schools, folklore and 'classical' music in tandem with transformations that stroked the integrity of the orchestra as a whole, paved the way for the birth of the concerto for orchestra. The concerto for orchestra became one of the iconic genres of twentieth-century music and embodied 'a positive vision of a world in a kind of harmony' in a number of works.
\end{abstract}

Keywords: Concerto for orchestra, History of the orchestra, Twentieth-century music, Inter-style synthesis, Bartók, Hindemith, Petrassi, Tippett, Lutosławski.

\footnotetext{
${ }^{1}$ Kyiv Gliere Municipal Academy of Music, E-mail: vr99@ukr.net
} 


\section{Introduction}

Early-twentieth century approaches to concerto strongly influenced late-twentieth century practices, including tradition and novelty in the concerto genre, inter-stylistic and inter-temporal fusions in concerto orchestra. These practices were so promising and the interest in earlier music was so intense at the turn of nineteenth and twentieth centuries that it might be considered as revolutionary, because the synthesis of material of different origins became a fundamental factor in the emergence of neo-classicism, neo-romanticism, and other 'neo' trends in all contemporary music. Busoni's open letter to Becker (1920) with the call to combine the principles of development and the logic of early music with the latest techniques of composition, and Stravinsky's slogan "Back to Bach" (1924)-recall his Concerto for Piano and Winds, definitely inspired by Bach's musiceffectively demonstrate this tendency.

The roots of this synthesis should be sought in an earlier period. Chopin introduced the mazurka into French art music. Liszt took on the challenge of combining ancient and specifically Hungarian musical idioms with nineteenth-century forms and styles. These composers established firmly transcultural perspectives by using rhythmic pulsation and characteristic scales and melodic intonation. Brahms offered a strong synthesis of the two styles' origins by unifying the 'classical' orchestral structure with the 'Romantic' practice of different features of orchestration as integrated domains in the orchestra of his Second Piano Concerto.

Although inter-stylistic and inter-temporal synthesis, as described above, appears in different symphonic genres such as the tone poem, the overture or the symphony, I place the concerto for orchestra at the center of my current study for the following reasons. Firstly, it combines the features of different genres, obviously due to the permanent rivalry between soloistic and sectional (or tutti) performances inside the orchestra. Secondly, it embodies both the 'old' and the 'new' approach to the concerto genre by reflecting on an early-twentieth century tendency to review longstanding musical forms. Thirdly, it reveals new traits of the orchestra by establishing a non-stop in-the-orchestra competition between the instruments without having a stable out-of-orchestra soloist (or soloists). Fourthly, it imbodies the searches for modifying the concerto and reflecting the main creative tendencies of the first quarter of the twentieth century (such as fusion of different origins in a single whole) in it. Joseph Kerman rightly assesses the early-twentieth century approach to the concerto as follows: 'More than with any other genre, probably, composers have felt free to play fast and loose with the implications, expectations, and values conveyed by the term concerto' (Kerman, 1999, p. 96).

\section{Literature analysis}

A number of works has been done on issues of the history of instrumental concerto (Joseph Kerman, Michael Roeder, Lev Raaben, etc.). These works cover all periods of the evolution of the genre, nevertheless, the concerto for orchestra remains largely unexamined. The process of its formation, the synthesis of different sources in the concerto for orchestra, the impact of the interstylistic, inter-temporal, and inter-arts fusions on the circumstances that led to appearance of the concerto for orchestra in the first quarter of the twentieth century have not been systematically analyzed until nowadays.

One can find just a few words about the origins of the concerto for orchestra in Kerman's book. A detailed and informative monograph about the instrumental concerto does not provide any clarification about the formation of the concerto for orchestra. The researcher only indicates that 'composers define the concerto for orchestra very liberally. Sometimes they seem to mean nothing more than a multimovement work for orchestra that prefers not to be appraised by the standards of the symphony, whatever they may be' (Kerman, 1999, p. 96). Thus, Kerman interprets the concerto 
for orchestra as a 'light' symphony, which is not really fair. Kerman indirectly defines the genre as 'a concerto for a good number of orchestra members, without any of them standing out as principle' (Ibid) drawing on Zoltán Kodály's Concerto for orchestra (1939-1940) which, in fact, preceded the Bartók's one.

Similarly, without mentioning the genesis of the genre, Ihor Savchuk refers only indirectly to the concerto for orchestra in the twentieth century. He rightly evaluates that, in symphonic music of the twentieth century, concerto's origin and symphonism as musical principles co-exist as developmental principles in a kind of dialogue (Savchuk, 2013, pp. 5-6). Like Kerman, he points out the existence of different genre models 'from the dominance of the features of concerto grosso and the symphony of reading of this genre in the works of many European composers in the second half of the twentieth century' (Savchuk, p. 6). However, Savchuk's idea of the 'dominance of concerto grosso and symphony features' is not completely understood; maybe he refers to the concerto grosso in the symphony genre? Unfortunately, the researcher has not provided specific examples except for contemporary Ukrainian composers. Such an approach makes it impossible to understand Savchuk's opinion clearly.

John Vinton is one of the very few who offers a definition for the concerto for orchestra. He assigns a basic origin to the genre and reveals (although very briefly) the roots of such a variant of concerto: 'born of neoclassicism, it [concerto for orchestra - V.R.] represents both a quintessential nostalgia and a consummate integration of historical elements: the nineteenth-century orchestra, the eighteenth-century symphony, and the seventeenth-century concerto' (Vinton, 1973, p. 15). This statement is quite clear and gives very useful and exact information about a synthetic nature of the genre. However, Vinton doesn't elaborate or analyze further. All he provides is a long list of concertos for orchestra without their classification or even a short consideration.

Kevin Davis interprets the term 'concerto for orchestra' as merely a rehearsal of a symphonic concert. He describes its peculiar atmosphere and narrates about the audience in a poet-like manner (Davis, 2008, p. 63). Surprisingly, he even does not mention a different meaning of the term, its interpretation of the concerto as a genre of symphonic music.

Naturally, the researchers recall the concerto for the orchestra in monographic works about a particular composer. But such an analysis has certain characteristic features, which will be discussed at the end of the literature review. Michael Tippett divided the orchestra into two equal ensembles in his famous Concerto for Double String orchestra (1938-1939) by creating a distinctive antiphonal effect. Thus, the composer, as Meirion Bowen assesses, 'engenders a new metamorphosis of the contrasts between concertino and ripieno groups which he [Tippett. - V.R.] admired in Hendel's Concerti Grossi' (Bowen, 1998, p. 150). Thomas Schuttenhelm rightly believes that such an approach to the orchestras contributes multi-dimensionality to the Concerto (Schuttenhelm, 2015, p. 35). Obviously, eighteenth-century concerto grosso was a principle model for Tippett's Concerto for Orchestra (1963) as well. Tippett's approach to the genre became one of the most evident examples for the most famous concerto for orchestra, the Bartók's Concerto.

For the vast majority of musicologists, the name of Bela Bartók and his Concerto for Orchestra (1943) are synonymous with the general term 'concerto for orchestra.' This has stood despite the appearance of numerous other samples in this genre during its nearly 100-year genesis and transformation. Therefore, when one researches the concerto for orchestra, he or she invariably finds himself in the following situation: when examining the genre, the focus is primarily restricted to an analysis of the Concerto of this Hungarian composer.

Danielle Fosler-Lussier concentrates on the historical circumstances that contributed to emergence of Bartók's Concerto: political reasons, general atmosphere of pre-war Hungary, and the 
forced emigration of the composer to the United States. She also mentions the opinion of another Hungarian composer, András Mihály, on the 'revolutionary' synthesis of Eastern European folklore and West European musical art in the works of Bartók in general, and emphasizes the Concerto for orchestra as 'the most outstanding example of these transformations' (Fosler-Lussier, 2000, p. 369).

Klára Móricz focuses on Bartok's Concerto as a creative phenomenon by comparing his initial drafts to his final version. She uses the term 'genesis' but she describes it as a process of transformation and refers to the 'genesis of the concerto for orchestra' in relation to this single work only rather than to the genre in general. Móricz indicates Romanian, Serbo-Croatian, and Turkish folklore as an important source of inspiration for the composer (Móricz, 1993, p. 182) and interprets the composer's idea about a 'concerto grosso-like composition' (Ibid, pp. 186, 188) as the actual germ. David Cooper stresses the importance of Bartók's works in ethnomusicology as a source for the Concerto as well (Cooper, 1996, pp. 4-7).

Benjamin Suchoff also argues that the primary source of the Concerto is Bartók's interest in folklore (Suchoff, 2000, p. 340). He asserts that Bartok's communications with his London-based publisher (Ralph Hawks) and conductor Sergey Koussevitzky contributed to his interest in the concerto genre. Bartók himself emphasized the key importance of synthesis in the creation of contemporary music. In particular, the composer treated folklore as a principle source of inspiration. On the other hand, Bartók stressed on the importance of 'Bach's counterpoint, Beethoven's progressive form, and Debussy's harmony' (cit. after Suchoff, 2000, pp. 340-346). Bartók's communications with the publisher and conductor gave form to this inspiration and established, in fact, the basis of the Concerto for orchestra.

This combination of folklore and professional knowledge is true not only for Bartók's Concerto but also for composers of the neo-folklore wave of the mid-twentieth century as well. Witold Lutosławski's Concerto for orchestra (1954) had almost the same initial impetus. The composer took Mazowsze collection of Polish folk music as his own source of inspiration. Lutosławski himself emphasized that he used in the Concerto an 'essentially different' technique of writing music which includes the 'combination of very simple diatonic tunes with such counterpoints and harmonious.' (cit. after Lee, 2002, p. 231). The tunes were mainly folk, the harmonies were sophisticated, and the counterpoints were atonal or non-tonal. The composer worked on these tunes as germinal motives. He transformed them by using 'sophisticated' harmonic, tonal, and timbral conditions and, thus, combined old and authentic folk origins with twentieth-century presentation techniques. Weaving one element into another, the composer creates completely new musical images. Douglas Lee considers Bartók's Concerto as a starting point for Lutosławski's approach to the genre (Lee, 2002, pp. 231-232). Probably, Baroque titles of movements, also mentioned by the researcher, need more attention and should be analyzed in more detail as an indirect origin of Lutosławski's Concerto as well.

\section{Discussion}

The literature review allows us to draw three principle conclusions. Firstly, despite several short references to the concerto for orchestra in the works of some researchers on Tippett, Lutosławski, etc., there is no systematical consideration on the origins of this genre. Secondly, most researchers focus on a single work albeit incredibly bright and highly aesthetic (Bartók's Concerto). Thirdly, there are no generalizations regarding the origins of the concerto for orchestra, nor detailed explanations of the reasons for its appearance in the first quarter of the twentieth century. The background, compositional process, and historical circumstances are well-considered in relation to Bartók's Concerto only. 
Such an approach does not seem correctly because it is obvious that the concerto for orchestra has a long pre-history and its origins should be sought in previous times, styles, and approaches as well as in early-twentieth century historical context and creative trends. To begin with, Paul Hindemith (1925), Alfredo Casella (1937), Michael Tippett (1938-1939) and Zoltán Kodály (1940) should be definitely mentioned among the composers who have already composed the concertos for orchestra before Bartók's Concerto (1943). Afterwards, older orchestral compositions must be considered in relation to their impact on the concerto for orchestra formation in the first quarter of the twentieth century. Thus, late seventeenth and early eighteenth-century concerto grosso with their instrumental groups' oppositions inside the orchestra (Lorenzo Gregory, Georg Muffat, George Fredrich Hendel, etc.), Bach's Brandenburg Concertos with a number of in-theorchestra soloists, and Vivaldi's concertos for a group of soloists and orchestra 'ensemble' concertos for three or more instruments' after David Yearsley (2003, p. 52) certainly must be taken into account as well.

Analysis of the literature shows extremely limited information about the genesis of the concerto for orchestra. This is particularly true regarding the process of its formation despite there being so many examples. It is surprising how little attention researchers have given this genre in the face of its popularity among composers and public throughout the twentieth century. Far from being completed, a list of the most famous concertos for orchestra should definitely include the works of Paul Hindemith, Georgio Ghedini, Goffredo Petrassi, Alfredo Casella, Bohuslav Martinù, Zoltán Kodály, Witold Lutosławski, Michael Tippett, Rodion Shchedrin, Andrei Ashpay, Myroslav Skoryk, Ivan Karabits, etc. This explains the necessity for the further research and defines the goal of this study: to identify and classify the principle sources of the genesis and development of the concerto for orchestra genre.

For hundreds of years the instrumental concerto has been one of the most popular symphonic genres among composers and public. Having arisen in the seventeenth century, the concerto by the beginning of the twentieth century still remains in high demand by composers and listeners, despite extremely dissimilar soloists and orchestras, different types of relationships between soloist and orchestra, 'pure' or 'synthesized' forms of the concertos (concerto-symphony, concerto-suite, concerto-rhapsody), as well as one or multimovement structures used for concertos. Thus, it seems quite logical the appearance of the concerto for orchestra precisely within the earlytwentieth century tendency to combine the 'old' and the 'new'.

The musicologists, who analyze the art tendencies of the first quarter of the twentieth century, have emphasized the most characteristic features of this period: the number of approaches towards the orchestra, coexistence of the different styles of presentation, and the variety of creative schools. Hindemith is one of the first composers to come to mind along with Stravinsky and Prokofiev in such a context. Hindemith's approach to the concerto genre allowed him to reconsider it (i.e. concerto for orchestra) with intent to introduce new elements and intensifying concerto-like competition within the midst of orchestra. The combination of 'old' polyphonic texture, twentiethcentury harmony caused a unique inter-stylistic mixture. These features, combined with the particular approach to the orchestra ('the orchestra of soloists'), led to the appearance of the first concerto for orchestra. Of course, it should be noted that concerto-like symphonic compositions in which soloistic and virtuoso approach to instruments and sections have been encountered before. For example, Rimsky-Korsakov's Spanish Capriccio or Richard Strauss's Ein Heldenleben. However, it was Hindemith's work that became the first in history titled as a concerto for orchestra.

Though the mixture I describe appears in different symphonic genres. it is the concerto that has a particular flexibility, depriving it of permanent features and characteristics, making it adaptable 
to endless modifications and letting it obtain one of the highest positions in the hierarchy of the symphonic genres in contemporary music. In fact, it is a kind of 'expansion of the concerto' after Michail Tarakanoff $(1988$, p. 191). He points out that the twentieth-century concerto replaces different symphonic genres such as the symphonic suite, overture, variations for orchestra, etc. (lbid).

This might help to explain the relatively late appearance of the concerto for orchestra: it took a long time to accumulate quantitative changes (increase in size, change of the number of instruments in each section, equality of all sections, strengthening of the in-the-orchestra solo, etc.) and to transform them into qualitative ones by the end of the nineteenth century (variety of types and sizes of orchestras, coexistence of different approaches to the orchestra, activity of a concerto origin in symphonic genres, inter-stylistic and inter-temporal fusions, etc.). It took more time still for the orchestra to evolve to a height that it could provide an aesthetic basis for renewal and rethinking of symphonic music. The latter tendency is perhaps the most important. Many prerequisite events had to take place within established and new genres before the arrival of the concerto for orchestra was possible. These include the use of non-classical harmony, transformation of the rhythmic origins, involvement of the latest techniques of composition, dissemination of different forms, the 'classical' methods of presentation, combination of listed and traditional ways of exhibiting material in symphonic music.

In describing Hindemith's musical style of 1925-1926, David Ewen explicitly writes that 'from this time on, Hindemith's music was to be a combination of Bach's polyphonic principles with the harmonic, rhythmic and melodic innovations of twentieth century music' (Ewen, 1991, p. 207). These stylistic features are important to understand the reasons of the appearance of the concerto for orchestra better. Hindemith's Concerto for orchestra is not very big and it has not a thundering sound. On the one hand, this can be explained by the traits of the style of Hindemith. On the second hand, another tendency should be taken into account: an inclination towards a smaller form. David Schneider points out that 'concertos of the 1920s and early 1930s tend to rebel against the expansive style of the pre-war period' (Schneider, 2003, 140). The researcher writes that in process of time, since ca. mid-1930s, more fully concertos come back. It seems that five-movements Bartók's Concerto, scored for a quite big orchestra with triple wind instruments, reflects this tendency.

lan Kemp assigns two predecessors that indirectly gave rise to the creation of the Hindemith's Concerto for orchestra: a) combination of the use of 'futuristic' and 'traditional' sound effects; b) quotation of foxtrot in Hindemith's 'classic' works of 1922-1923 (Kemp, 1984, p. 243). In other words, it was a synergy of such origins that could not be connected in a whole in any way, in any earlier periods of time. However, 1920s was a period in which the juxtapositions of different origins were very popular. They can be considered as one of the leading tendencies in music. Many works were written in the context of incredible growth in interest in the past such as Prokofiev's Classical Symphony, Gershwin's Rhapsody in Blue and his Piano Concerto in F, Copland's Piano Concerto, Stravinsky's Concerto for Piano and Wind Instruments and his Pulcinella.

Petrassi's concertos (and in particular, his First Concerto per orchestra) must be also included in this list and mentioned in the context of this study: any other master had written eight concertos for orchestra during his long life (1904-2003)! They are different in size, number of movements, techniques of composition and type of orchestra: the genre became the life path of Petrassi. These concertos for orchestra 'constitute the core of Petrassi's orchestral output' (MacDonald, 1995, p. 3). His First Concerto (1933-1934) is a more than noticeable contribution to neo-classicism movement. Such an approach definitely continues Hindemith's understanding of the genre. Calum MacDonald emphasizes that Baroque concerto grosso was a principle model for Petrassi. The composer 
embodied eighteenth-century principles in his twentieth-century concertos with "kaleidoscopic blending or antiphonal oppositions of instrumental groups' (MacDonald, p. 4). MacDonald is one of the very few researchers who pay attention to the origins of the concerto for orchestra. He points out that he knows 'of no study that indicated the origins of the 'Concerto for Orchestra' (MacDonald, p. 2). The researcher indicates attempts to imitate the Baroque style at the beginning of the twentieth century (Reger's Konzert im alten Stil) and Hindemith's Concerto for orchestra as the most obvious reasons for the appearance of the concerto for orchestra. Undoubtedly, such a list looks too short and incomplete. Nevertheless, the researcher's interest in the reasons for the appearance of the concerto for orchestra and his statement on the lack of research on this subject deserve attention.

The early-twentieth century tendency for synthesis of different approaches, combination of dissimilar origins, and inter-stylistic and inter-temporal fusions was the first, most important and most general factor for the birth, development, and popularization of the concerto for orchestra. Multifunctional, different in structures and sizes, dissimilar in approaches orchestras were the perfect platform for the appearance of the concerto for orchestra. These changes in relation to the orchestra occurred at the turn of the twentieth century. One should think about the differences between the nineteenth and twentieth centuries. They were firstly due to transformations in the interpretation of the orchestra. This was a multi-vector shift resulting from a permanent transformation in society, the birth of new style trends and music schools as well as changes in the outlook of composers and performers. As a consequence, the orchestra soared to new heights of evolution. Through the centuries constant renewal has been clearly inherent in the orchestra. A comparison of the beginning of the nineteenth and twentieth centuries shows obvious transformations: the list of tools, structures and principles of functioning varied in intensity, purpose and, most fundamentally, results. The beginning of the twentieth century is not merely a 'formal' update of the orchestra with unchanged spheres of use and minor variations in instrumental composition. No, the twentieth century marked the beginning of a new era of the orchestra: A limitless number of interpretations of the symphony orchestra in this period of time and the very notion of 'normal' and 'un-normal' in relation to this musical institution disappeared forever. This was a matter of principle, for a radical revision of the orchestra's attitude had no historical analogy. This is the first significant difference between the two centuries.

The second is the variety of functions of the orchestra. It appeared in secular and everyday life, at a youth party and aristocratic ball, at a concert at the Royal Palace and in a cabaret with a strange reputation in the suburbs. The twentieth-century orchestra did not lose its lofty position in the music hierarchy. The most sophisticated and 'classical-like' compositions (Mahler's or Glazunov's symphonies, for example) are to be performed in it. At the same time, the orchestra has soon become a popular institution to present the most provocative and innovative works (Stravinsky's Rite of Spring, Prokofiev's Scythian Suite or Richard Strauss's Salome, for instance). This contributed to its prevalence, active and more diverse applications. The orchestra reflects society in miniature: Christian Merlin emphasizes that the orchestra contains soloists and 'tuttists', artists and laborers, creative interpreters and mechanical performers, aristocrats and proletarians (Merlin, 2017, p. 163). The 'slice' of society in a confined space becomes noticeably concentrated. It gives this genre universalism and flexibility-traits inherent in the orchestra throughout history-and best reflects the profound changes and public demands around the world for its transformation in the first 
quarter of the twentieth century. The orchestra's 'social-likeness' was less evident in the nineteenth century.

The third difference between the two centuries was the emergence of completely new instruments, structures and spheres using jazz, variety of percussion orchestras (the brass band gained popularity during the French Revolution) and the formation of combined structures for the orchestra. These tendencies led to a completely new approach to the orchestra in the early twentieth century as well as an enormously increased potential. This energy needed a way out. Thus, was born a genre that should and could embody all these changes.

No matter how important the changes in the orchestra's functions and structure along with the fusion of different origins for the genesis of the concerto for an orchestra were, it is true that it was not a single factor which influenced the genre transformations of the concerto.

The second principle factor which led to the appearance of the concerto for orchestra was the approach to the sound of the orchestra as a whole. These searches resulted in revisions in the presentation techniques for musical material. First of all, it was the divisi. It was quite often to split of the string instruments for different composers in the nineteenth century. One can find a number of examples (mostly in relation to the violins) in Beethoven's, Berlioz's, Liszt's, Wagner's, Tchaikovsky's, etc. scores. The divisi in relation to the violas or cellos was much rarer (although Beethoven's divisi of the group of cellos in the Allegretto from his Seventh symphony recalls to mind immediately). By the beginning of the twentieth century, this feature had transformed significantly. There was active and diverse use of divisi for all stringed instruments for 2, 3 or 4 parts (the beginning of Debussy's Nocturnes) and even more (Stravinsky's Sacred Spring). In this way the basis for division by desks (Richard Strauss's Don Quixote) was formed. The solo string became much more active inside the orchestra as well (the violin solo in Rimsky-Korsakov's Scheherazade, the viola sola in Richard Strauss's 'Dance of the Seven Veils' from Salome or six violas, two cellos and two double bass soli in Stravinsky's Sacred Spring.

Each instrument from every section is treated equally in the twentieth-century orchestra. Unusual instruments appear much more often at the end of the nineteenth century. Such instruments almost always are interpreted as 'in-the-orchestra' soloists. One can recall the piano in Debussy's Printemps, the hammer in Mahler's Sixth Symphony, the oboe d'amour in Ravel's Bolero, the mandolin and guitar in Mahler's Seventh Symphony, the organ in Saint-Saëns' Third Symphony, etc. In such a context one should recall muted brass instruments section in Schoenberg's Kammersimfonie, instant changes in the method of sound extraction on stringed instruments (Stravinsky's Sacred Spring), exclusive play on open strings (Berg's Concerto for Violin and Orchestra), use of an extremely large orchestra (Mahler's Eight Symphony, Richard Strauss's tone poems, Stravinsky's Sacred Spring, Prokofiev's Scythian Suite). The purpose of these novel techniques was to infuse the new era with unusual artistic images. These changes are also due to the unprecedented high demands for performing skills (Rimsky-Korsakov's Spanish Capriccio) and even true virtuosity (Richard Strauss's Don Quixote or Ein Heldenleben). All led to the emergence of a new sound quality for the orchestra. These changes appeared in all genres of symphonic music, and simultaneously created a separate, proper symphonic and concerto mix. This complex was the second set of reasons for the appearance of the concerto for orchestra, which embodied them all.

It is worthy to mention that Lutosławski himself marked the problem of the sound in twentieth-century orchestra as one of the deepest and, in fact, as a problem that has not a true solution. The composer explains this to the fact that new instruments cannot be compared with "the rich and noble timbre of old instruments" (Lutosławski, 1970, p. 129) but at the same time "the limitations which the old instruments impose on the contemporary composer are gallingly 
restrictive" (Ibid). It seems that early-twentieth century composers were aware of this but still tried to offer variants to find an interesting sonic decision.

The chamber orchestra's role was significant in the genesis of the concerto for orchestra and this should be treated as the third factor for the formation of the concerto for orchestra. The importance of each of instrument increases significantly in a chamber orchestra. Therefore, the chamber orchestra has enhanced the concerto's origin due to the fact that 'in chamber symphonies, the composers operated with the sounds of solo instruments instead of thick and powerful sound masses. $<\ldots . .>$ Thus, the space for the revival of the concerto-like dialogue opens up within chamber symphony that sometimes gives such a work clear features of a concerto for orchestra' (Tarakanoff, 1988, p. 188). The roots of chamber symphonies such as Schoenberg's and Schreker's chamber symphonies, Webern's Symphony, Hindemith's Kammermusiken, and Stravinsky's Concerto for Piano and Wind Instruments and use of emphasized small orchestras in general one can find in Bach's Brandenburg Concertos. It laid the foundation for the in-the-orchestra solo and paved the way for equality of instrument sections within the reign of counterpoint. The basis for inter-stylistic and inter-genre mixtures in Hindemith's Kammermusiken was shaped by Hindemith's interest in baroque musical forms, his refusal to use 'classical' sonata form, his reliance on contrast instrumental sections and his particular attention to horizontal lines. This is especially true for the Hindemith's Concerto for Orchestra in which the composer 'employed a full orchestra, but one whose wind and brass are equivale the strings and whose balance is therefore radically different from the form the 19thcentury norms' (Kemp, 1984, p. 249). This is somewhat controversial, since the romantic approach to the orchestra, especially in the second half of the nineteenth century, provided balance between the sections.

During many centuries the string section was a leading one in the orchestra. By analyzing the orchestra of Jean Batiste Lully, Alan Louvier and Pierre Albert Castanet point out that, in fact, all subsequent evolution of the orchestra should be associated with the gradual addition of new and instruments to the string section (Louvier \& Castanet, 1997, p. 13). However, by the last quarter of the nineteenth century a new orchestra had formed. There were no more subordinate and dominate sections or instruments. Any strings, wood-wind, brass or percussion instrument could be used as the in-the-orchestra soloist in a symphonic composition. This interpretation of the orchestra opened the door to Mahler's approach and the appearance of an 'orchestra of soloists'. Here the composer views the orchestra as a community of in-the-orchestra soloists who compete among themselves rather than as a single united whole. I believe that it was Mahler who promoted the idea of a concerto within his symphonies. He focused attention on the merit of each timbre, multi-layered depth of sound, and musical vibrancy. His soloists counteracted the monolithic tendencies of the orchestra by means of a concerto-like competition in its midst. A concerto origin not only appeared within the symphony but saturated it. 'The concerto inevitably perceives, absorbs the achievements of the symphony, even to the endeavor to "build a new world" within the instrumental competition.' (Tarakanoff, 1988, p. 191). Thus, intensifying and diversifying the in-the-orchestra solo ${ }^{2}$ form the fourth set of reasons for the appearance of the concerto for orchestra: 'Firstly, a soloist sounds more nuanced; secondly, more expressively. It plays with a more heart-felt vibrato, it makes an "approaching" from one note to another between the sounds for expressiveness, enhances its aspiration for desire the melody' (Fortunatoff, 2004, p. 87). In the seventeenth and eighteenth

\footnotetext{
${ }^{2}$ According to my own systematization of solo I distinguish:

1) A solo of an instrument that plays in the orchestra. I call this case the 'inside-the-orchestra' or 'in-theorchestra' solo as in a symphony or overture.

2) A solo of an instrument that is not a part of the orchestra. I call it the 'out-of-orchestra' solo. For example, the piano in the concerto for piano and orchestra.
} 
centuries, composers also used different types of solos in the orchestra. The importance of in-theorchestra solos increased in the nineteenth century due to the exceptional expressiveness of timbres, very high technique requirements for the performers, expansion of the orchestra (sometimes hypertrophied), unusual soloistic performance (double-bass or contrabassoon) and introducing unusual instruments (mandolin, oboe d'amour or saxophone) in the body of the orchestra. The emergence of a number of in-the-orchestra solos paved the way to clarify grandiose tutti, to balance the power of sound, and to enhance the importance of each performer no matter what section it belongs to. Unusual solos by the rare saxophone (Ravel's Bolero), double bass (Mahler's First Symphony), tuba (Mahler's Sixth Symphony) or percussion instruments (Mahler's Third Symphony, Prokofiev's Scythian Suite), contrabassoon in Dukas's L'Apprenti sorcier and oboe d'amour in Debussy's Gigues brought special credibility of presentation to the orchestra, especially on 'pure' timbres. This encouraged concerto-like competition and brought chamber and lyrical features into a giant-sized orchestra.

By the end of the nineteenth century the development of ensembles-in-orchestra became an important innovation that embodied a new approach to the orchestra. Examples include a string quartet in Mahler's Fifth Symphony, wood-wind ensembles in Richard Strauss's Till Eulenspiegel and wood and string instrument ensembles in his Don Quixote. Of course, composers had taken special interest before in the assignment of some sections of the orchestra (wood-wind ensembles in Mozart's piano concertos K. 482 or K. 488, Beethoven's Second Piano Concerto, wind and piano ensembles in Brahms's Second Piano Concerto). But in the late nineteenth century such an approach to orchestral sections became notably more regular, active and diverse (percussion ensemble in Mahler's Third Symphony). An emerging view of the orchestra as a gigantic chamber ensemble combined with a number of obbligatos of soloists-in-orchestra became an important factor in forming a concerto for orchestra.

The fifth set of reasons for the appearance of the concerto for orchestra was the growth of theatricality in symphonic music through the grotesque (Mahler's First Symphony), the tragedy (Stravinsky's Petrushka) or the irony (Richard Strauss's Till Eulenspiegel). The roots of this theatricality should be found in the post-romantic's approach to the orchestra (Richard Strauss, Mahler, Dukas) to display 'fantastic, mystical images embodied in symbolism and allegory' (Stakhevich, 2018, p. 90). The exaggerated characters, who acted as if on a stage were performed as relief images, delicate contrasts, and unusual sounds due to timbre effects or rare instruments. Recall, for example Richard Strauss' Till Eulenspiegel, Dukas's L'Apprenti sorcier, the mandolin and the guitar in Mahler's Seventh Symphony, the piano in Shostakovich's First Symphony, the saxophone in Ravel's Bolero, and the oboe d'amour in Debussy's Images. The soloists act as real characters and promote a concerto in the symphony or in the symphony poem. The appearance of stage-like symphonic composition demonstrates a new kind of inter-genre synthesis.

The sixth group of factors includes the transformation of longstanding genres, as well as the intense penetration of one genre into another. The blending of different origins produced a result that was greater than the sum of the parts. Consider closely the symphonization of the instrumental concerto (Prokofiev) and the ballet (Stravinsky), the mutual saturation of the concerto and the symphony (Mahler, Saint-Saëns), as well as the symphonic poem (Richard Strauss, Dukas) or paraphrases (Sarasate). Combining the features of several genres into one was especially evident due to a concerto and concertizing. A concerto appears due to the increasing the role of an individual performer in the orchestra and led to loosening the monolithic of the single whole. Another obvious result of combining several genres was concertizing. It is due to the activation of pure timbre with bright register and dynamic comparisons, emphasizing of the dialogues, colorful oppositions of the instruments and instrumental groups. These features contributed to the strengthening of the value 
of each performer and 'encouraging' composers to further expand functions and possibilities of the orchestra in a whole.

The seventh set of factors is related to the steady increase of the colorfulness of the orchestra. This follows directly from the factors described earlier. From the beginning of the romantic era, sophistication and relief, as well as brightness and brilliance were important tools for packing sound with emotion. Powerful examples include Richard Strauss's orchestra with stunning tutti, Mahler's orchestra with an incredible palette of instrumental soloists, Stravinsky and Ravel with an unrestrained rhythmic pulsation, and lastly Rimsky-Korsakov with brilliant sound based on subtle nuances of dynamics and a rainbow of colors from all instruments. They actively and persistently created feedback in orchestral compositions.

\section{Conclusions}

The appearance of the concerto for orchestra in the twentieth century is one of the most successful advancements in the symphonic genre. It reflected the multicultural and polystylistic art of that century. In the preceding century developments had occurred in the concerto such as virtuoso and symphonic concerts, as well as many varied relationships between soloist and orchestra. These refute the view that 'the concerto as a genre proved to be much more "conservative", typologically more stable than a symphony' (Tarakanoff, 1988, p. 190). The ongoing evolution of the concerto in the twentieth century was even more significant, as evidenced by Ravel's concerto for the left hand, Prokofiev's Concerto-symphony, Szymanowski's Symphonie concertante, etc. There was endless variety of timbre for the soloist. Examples include Glière's Concerto for voice and orchestra, Tailleferre's Concerto for two pianos, a choir and a quartet of saxophonists. These are a convincing testimony to the genre's exclusive flexibility, its modernity and its constant demand. However, these qualities of the genre alone would not have been enough to give rise to the concerto for orchestra. Rather a unique combination of many other contributors was necessary for it to emerge. These included public demand for a renovation of established forms, interest in old, in particular, baroque music in the context of a tangible tendency to synthesize extremely different origins. These interstylistic and inter-genre mixtures led to deep transformations of the orchestra's comprehension, changes of its structure, function and role, enhancement and reinforcement. Respectively, concerto performances in symphonic music made quite anticipated the emergence of a genre in which the listed appeared as fully as possible. The concerto for orchestra became the quintessence of the leading trends and challenges of its time.

At the beginning of the twentieth century composers demonstrated endless interest in 'individualization of approaches' as to any side of creative process as Olena Samoilenko notes (Samoilenko, 2003, p. 6). It means that the orchestra, harmony, genre, style, etc. might receive very different interpretations. Fusion of styles and juxtaposition of traditions and innovations belong to mainstream tendencies of the first quarter of the twentieth century. The appearance of the concerto for orchestra genre, as an inter-stylistic mixture, bares testimony to the musical mindset of the times.

Hindemith's Concerto for orchestra and Petrassi's First Concerto for orchestra paved the way for an 'inter-style type' of the concerto for orchestra. Tippatt's Concerto for orchestra, 1962-1963, and Elliott's Concerto for orchestra (1969) continued to use such a type of the concerto for orchestra. Kodály's, Bartók's and Lutosławski's represented another type of synthesis. These composers took folklore tunes as germinal motives and by weaving them into contemporary harmonic and tonal systems, created an 'inter-specific' type of the concerto for orchestra. Shchedrin (Concerto for orchestra 'Mischievous folk ditties', 1963) and Skoryk (Concerto for orchestra 'Carpathian', 1972) used such a type of concerto in their approaches to the genre in the second half of the twentieth century. 
Despite the obvious historical need for its appearance, the concerto for orchestra did not become the universal manifestation of the times. Obviously, the conscious intention behind any creative act can explain this. But the concerto for orchestra opened new and varied possibilities for composers, by compelling them to look at the symphonic genre through the prism of the concerto. Cooper aptly wrote that the concerto for the orchestra is 'a positive vision of the world as a certain harmony in which chaos and order-the primordial enemies-are maintained in a dynamic equilibrium' (Cooper, 1996, p. 2). His words referred to Bartók's Concerto, but definitely they also apply to the concerto for orchestra as a whole, a genre that embodied the perspective of the entire twentieth century.

This study contributes new analytical and cultural-historical perspectives to our understanding of the concerto genre. It demonstrates the synthesis of different origins as a principle tendency in twentieth-century culture including painting, cinema, theatre, design, etc. The research fosters a better understanding of the roles that a contemporary orchestra plays today because it is the synthesis of a number of sources and approaches that is a cornerstone to understand what the orchestra is nowadays.

\section{References}

Berger, A. (2002). Reflections on an American Composer. Berkeley: University of California Press.

Bowen, M. (1998). Michael Tippett. New York: Robson Books Parkwest.

Cooper, D. (1996). Bartók: Concerto for Orchestra. Cambridge: Cambridge University Press.

Davis, K. (2008). Confidence for Terrified Hearts: Concerto for Orchestra and Writing Center. Writing on the Edge, 19(1), 63-67.

Ewen, D. (1991). The world of twentieth-century music (2nd ed.). London: Robert Hale \& Company.

Fortunatoff, Y. (2004). Lectures on the history of orchestral styles. Moscow: Muzyka.

Fosler-Lussier, D. (2000). Bartók's Concerto for Orchestra in Postwar Hungary: A Road Not Taken. International Journal of Musicology, 9, 363-383.

Kemp, I. (1984). Hindemith. The New Grove modern masters: Bartók, Stravinsky, Hindemith. New York: W.W. Norton and company, 229-282.

Kerman, J. (1999). Concerto Conversations. Cambridge: Harvard University Press.

Lee, D. (2002). Masterworks of 20th-century music: the modern repertory of the symphony orchestra. New York: Routledge.

Louvier, A., \& Castanet, P. A. (1997). L'orchestre. Paris: Combre.

Lutosławski, W. (1970). Witold Lutosławski. The orchestral composer's point of view: essays on twentieth-century music by those who wrote it. Norman: University of Oklahoma Press. 128-151.

MacDonald, C. (1995). 'Tutt' ora vivente': Petrassi and the Concerto Principle. Tempo, (194), 2-10.

Merlin, C. (2012). Au coeur de l'orchestre. Paris: Fayard.

Móricz, K. (1993). New Aspects of the Genesis of Béla Bartók's 'Concerto for Orchestra': Concepts of 'Finality' and 'Intention'. Studia Musicologica Academiae Scientiarum Hungaricae, 35(1/3), 181-219. 
Raaben, L. (2000). Violin concertos of Baroque and Classicism. St. Petersburg: Publishing House Herzen Russian State Pedagogical University.

Roeder, M. T. (1994). The History of the Concerto. Portland: Amadeus Press.

Samoilenko, E. (2003). Genre nature of the instrumental concerto and concerto compositions of Andrei Eshpay. Extended abstract of PhD thesis. Moscow: Gnesins Russian Academy of Music.

Savchuk, I. (2013). Ivan Karabits: An attempt to approach understanding. In: Karabits, I. Three Concertos for Orchestra. Kyiv: Muzychna Ukraina.

Schneider, D. (2003) Contrasts and common concerns in the concerto 1900-1945. The Cambridge Companion to the Concerto. Edited by S. Keefe. New York: Cambridge University Press. 139-160.

Schuttenhelm, T. (2013). The Orchestral Music of Michael Tippett: Creative Development and the Compositional Process. London: Cambridge University Press.

Stakhevich, G. (2018). Piano concerto of XVIIIth-XIXth centuries: style transformations of the genre. Kherson: Molodyj Vcheniy, 6(58), 87-91.

Suchoff, B. (2000). Background and Sources of Bartók's Concerto for Orchestra. International Journal of Musicology, 9, 339-361.

Tarakanoff, M. (1988). Symphony and instrumental concerto in Russian Soviet music (60-70s). Ways of development. Moscow: Sovietski compositor.

Vinton, J. (1973). For Jan LaRue: The Concerto for Orchestra. Notes. 30(1), 15-23.

Yearsley, D. (2003). The concerto in northern Europe to c. 1770. The Cambridge Companion to the Concerto. Edited by S. Keefe. New York: Cambridge University Press. 53-69. 